\title{
GAMBARAN TINGKAT DEPRESI PADA PASIEN PENYAKIT GINJAL KRONIK DENGAN HEMODIALISIS DI RSI SITI RAHMAH DAN RST DR. REKSODIWIRYO PADANG
}

\author{
Riskal, $\mathrm{F}^{1}$, Annisa, $\mathrm{M}^{2}$, Dewi, $\mathrm{NP}^{3}$ \\ ${ }^{1}$ Mahasiswa Fakultas Kedokteran Universitas Baiturrahmah, Padang, Indonesia \\ ${ }^{2}$ Bagian Psikiatri, Fakultas Kedokteran Universitas Baiturrahmah, Padang Indonesia \\ E-mail : mutiaraanissa@fk.unbrah.ac.id \\ ${ }^{3}$ Bagian Anatomi, Fakultas Kedokteran Universitas Baiturrahmah, Padang Indonesia \\ E-mail : $\underline{\text { nadiapurnamadewi@ fk.unbrah.ac.id }}$
}

\begin{abstract}
Abstrak
Latar Belakang: Pasien gagal ginjal kronik dengan Laju Filtrasi Glomerulus $<15 \mathrm{~mL} / \mathrm{menit}$ harus menjalani terapi hemodialisis untuk mengganti fungsi ginjal. Pasien yang menjalani terapi hemodialisis dapat mengalami masalah psikologis salah satunya adalah depresi. Tujuan penelitian ini adalah untuk mengetahui gambaran tingkat depresi pada pasien penyakit ginjal kronik yang menjalani hemodialisis di RSI Siti Rahmah dan RST Dr. Reksodiwiryo, Padang. Metode: Penelitian ini merupakan peneltian deskriptif dengan pendekatan cross sectional. Sampel yang digunakan sebanyak 37 responden dengan teknik pengambilan sampel random sampling. Penelitian dilakukan pada tanggal 12-22 agustus 2019 di Ruang Hemodialisis RSI Siti Rahmah dan RST Dr. Reksodiwiryo, Padang. Hasil penelitian menunjukkan bahwa sebagian besar usia responden adalah 50-59 tahun yaitu 15 responden $(40,5 \%)$, jenis kelamin responden adalah perempuan yaitu 21 responden $(56,8 \%)$, status perkawinan responden adalah kawin yaitu 27 responden (73\%), tingkat pendidikan responden adalah SMU yaitu 18 responden $(48,6 \%)$, pekerjaan responden adalah tidak bekerja yaitu 13 responden $(35,1 \%)$ dan penghasilan perbulan responden adalah berpenghasilan rendah yaitu 27 responden (73\%). Gambaran tingkat depresi pada pasien penyakit ginjal kronik yang menjalani hemodialisis adalah termasuk kategori depresi ringan yaitu sebanyak 19 responden (51,3\%). Kesimpulan penelitian ini didapatkan sebagian besar tingkat depresi pada pasien penyakit ginjal kronik yang menjalani Hemodilalisis di RSI Siti Rahmah dan RST Dr. Reksodiwiryo Padang, termasuk kategori depresi ringan.
\end{abstract}

Katakunci — Depresi, Penyakit Ginjal Kronik, Hemodialisis.

\begin{abstract}
Background: Chronic kidney disease patients with glomerulus filtration rate $<15 \mathrm{~mL}$ must undergo hemodialysis therapy in order to replace kidney function. Patients underwent hemodialysis therapy may experience effects on psychological aspects such as depression. Objective of this research was to identify Depression Level of Chronic Kidney Disease patients underwent hemodialysis therapy at Siti Rahmah Islamic Hospital and Dr. Reksodiwiryo Military Hospital, Padang. Method:This study was descriptive one with a cross sectional approach. The research conducted on 12-22 August 2019 in the Hemodialysis Room at Siti Rahmah Islamic Hospital and Dr. Reksodiwiryo Military Hospital, Padang. Results showed that the majority of respondents aged 50-59 years was 15 respondents (40,5\%), 21 respondents mostly female patients (56.8\%), 27 respondents were mostly married (73\%), 18 respondents were high school gradutes (48,6\%), 13 respondents respondents did not work (31.2\%) and most of respondent had low income $73 \%$. Depicting the level of depression in patients with chronic kidney disease undergoing hemodialysis is mostly included in the category of mild depression as many as 19 respondents (51,3\%). Conclusion:There is the Most levels of depression in
\end{abstract}


12 Heme, Vol II No 1

January 2020

patients with chronic kidney disease under hemodilalysis therapy at Siti Rahmah Islamic Hospital and Dr. Reksodiwiryo Military Hospital Padang, including mild depression category.

Keywords - Depression, Chronic Kidney Disease, Hemodialysis 


\section{Pendahuluan}

Penyakit Ginjal Kronik (PGK) adalah suatu gangguan pada ginjal yang ditandai dengan abnormalitas struktur ataupun fungsi ginjal yang berlangsung lebih dari 3 bulan. Penyakit Ginjal Kronik ditandai dengan satu atau lebih tanda kerusakan ginjal yaitu albuminuria, abnormalitas sedimen urin, elektrolit, histologi, struktur ginjal, ataupun adanya riwayat transplantasi ginjal, juga disertai penurunan laju filtrasi glomerulus. ${ }^{1}$

Prevalensi PGK meningkat di berbagai wilayah di seluruh dunia. Prevalensi PGK derajat II sampai V terus meningkat sejak tahun 1988 sejalan dengan peningkatan prevalensi penyakit diabetes dan hipertensi yang juga merupakan penyebab $\mathrm{PGK}^{2}{ }^{2}$

Prevalensi penyakit ginjal kronik meningkat seiring bertambahnya usia, didapatkan meningkat tajam pada kelompok umur 25-44 tahun $(0,3 \%)$, diikuti umur 45-54 tahun $(0,4 \%)$, umur 55-74 tahun $(0,5 \%)$, dan tertinggi pada kelompok umur $\geq 75$ tahun $(0,6 \%)$. Prevalensi pada laki-laki $(0,3 \%)$ lebih tinggi dari perempuan $(0,2 \%){ }^{3}$

Prevalensi PGK di Sumatera Barat sebesar $0,2 \%$. Prevalensi PGK tertinggi sebanyak 0,4\% yaitu di Kabupaten Tanah Datar dan Kota Solok. Prevalensi PGK di Kota Padang adalah 0,3\%. Kejadian tertinggi PGK di Sumatera Barat adalah pada kelompok umur 45-54 tahun sebanyak $0,6 \%{ }^{4}$

Penyakit ginjal kronik menyebabkan penurunan fungsi nefron secara progresif sehingga mengakibatkan penurunan laju filtrasi glomerulus menjadi $<15 \mathrm{ml} /$ menit. Penurunan laju filtrasi glomerulus ini menyebabkan penurunan yang besar pada ekskresi air dan zat terlarut oleh ginjal. Penurunan fungsi nefron lebih lanjut ini menyebabkan tertahannya cairan dan elektrolit di dalam tubuh sehingga ekskresi cairan dan elektrolit menjadi sedikit. Hal ini ditandai dengan oliguria yaitu produksi urin
$<200 \mathrm{ml} / 12$ jam atau anuria yaitu produksi urin $<50 \mathrm{ml} / 12$ jam. Penurunan fungsi nefron yang progresif juga mengakibatkan peningkatan kadar urea dan kreatinin serum di dalam tubuh. ${ }^{5}$

Pasien yang menderita penyakit ginjal kronik stadium akhir atau end-stage, yaitu pada Laju Filtrasi Glomerulus (LFG) kurang dari $15 \mathrm{ml} / \mathrm{mnt}$ memerlukan terapi pengganti ginjal berupa hemodialisis, peritoneal dialisis atau transplantasi ginjal. ${ }^{12} \mathrm{Pada}$ penderita gagal ginjal, kondisi tubuh yang melemah dan ketergantungan pada mesin-mesin dialisis sepanjang hidupnya akan menyebabkan penderita dituntut untuk dapat menyesuaikan diri secara terus menerus sepanjang hidupnya. Akibatnya akan menjadi stressor fisik yang berpengaruh pada berbagai dimensi kehidupan pasien yang meliputi biologis, psikososial, sosiologis dan spiritual. Perasaan tersebut dapat menimbulkan perasaan tertekan dan tidak nyaman bahkan dapat berujung pada munculnya gangguan mental seperti depresi. ${ }^{6}$

Depresi merupakan salah satu dari gangguan mood yang utama. Depresi yaitu perasaan hilangnya energi dan minat, perasaan bersalah, kesulitan berkonsentrasi, hilangnya nafsu makan, dan pikiran tentang kematian atau bunuh diri. Tanda dan gejala lain gangguan mood adalah perubahan tingkat aktivitas, kemampuan kognitif, pembicaraan dan fungsi vegetatif seperti tidur, nafsu makan, aktivitas seksual dan irama biologis lainnya. Perubahan tersebut hampir selalu menyebabkan gangguan fungsi interpersonal, sosial, dan pekerjaan. ${ }^{7}$

Prevalensi depresi berat pada populasi umum adalah sekitar $1,1 \%-15 \%$ pada laki-laki dan 1,8\%-23\% pada wanita, namun pada pasien hemodialisis prevalensinya sekitar 20\%-30\% bahkan bisa mencapai $47 \% .^{8}$ Pasien yang menjalani hemodialisis seringkali mengalami gejala-gejala depresi seperti perubahan suasana hati berupa kesedihan, kesepian dan apatis, timbul perasaan untuk menyalahkan 
diri sendiri, keinginan untuk menghukum diri sendiri, adanya perubahan gangguan tidur, gangguan makan, kehilangan nafsu seksual, serta perubahan terhadap aktivitas, bahkan sampai berkeinginan untuk bunuh diri. $^{6}$

Kondisi afektif yang negatif pada pasien gagal ginjal juga seringkali bertumpang tindih gejalanya dengan gejala-gejala pasien penyakit ginjal kronik yang mengalami uremia seperti iritabilitas, gangguan kognitif, ensefalopati, akibat pengobatan atau akibat hemodialisis yang kurang maksimal. ${ }^{8}$ Selain itu masalah finansial dan perasaan takut akan kematian juga sangat berpengaruh pada kondisi psikologis sehingga memperberat kondisi depresi pasien. ${ }^{6}$

Pasien yang menjalani hemodialisis banyak mengalami masalah psikososial sehingga meningkatkan kebutuhan pasien untuk mendapatkan perawatan holistik, yaitu termasuk perhatian dalam lingkungan dan mendapatkan dukungan dari keluarga. Jika pasien yang menjalani hemodialisis dirawat dan mendapatkan dukungan penuh dari keluarga, maka masalah psikososial ini bisa dicegah atau diminimalisir. ${ }^{9}$

Berdasarkan latar belakang tersebut penulis tertarik untuk melakukan penelitian "Gambaran Tingkat Depresi Pada Pasien Penyakit Ginjal Kronik Yang Menjalani Hemodialisis Di RSI Siti Rahmah dan RST Dr. Reksodiwiryo, Padang”.

\section{Metode Penelitian}

Penelitian ini merupakan penelitian deskriptif kategorik dengan metode cross sectional yang bertujuan untuk mengidentifikasi tingkat depresi pada pasien penyakit ginjal kronik yang menjalani hemodialisis di RSI siti rahmah dan RST Dr. Reksodiwiryo Padang dengan menggunakan kuesioner PHQ-9. Penelitian ini dilakukan pada bulan Maret 2018-Oktober 2019 dengan besar sampel 37.

Populasi penelitian ini adalah semua pasien
PGK yang menjalani Hemodialisis yang berobat rawat jalan di RSI Siti Rahmah dan RST Dr. Reksodiwiryo Padang. Kriteria inklusi adalah semua pasien PGK yang menjalani Hemodialisis di RSI Siti Rahmah dan RST Dr. Reksodiwiryo, Padang. Kriteria eksklusi adalah pasien dengan kondisi yang tidak memungkinkan dan menolak untuk diwawancara.

\section{HASIL}

Penelitian ini dilakukan terhadap 37 orang pasien PGK yang menjalani Hemodialisis di RSI Siti Rahmah dan RST Dr. Reksodiwiryo Padang.

Tabel 1. Karakteristik Dasar Pasien HeMOdIALISIS YANG MENGALAMI DEPRESI

\begin{tabular}{|c|c|c|}
\hline Variabel & $F$ & $\%$ \\
\hline \multicolumn{3}{|l|}{ Usia } \\
\hline 20-29 tahun & 2 & 5.4 \\
\hline 30-39 tahun & 2 & 5.4 \\
\hline 40-49 tahun & 6 & 16.2 \\
\hline 50-59 tahun & 15 & 40.5 \\
\hline 60-69 tahun & 9 & 24.3 \\
\hline$\geq 70$ tahun & 3 & 8.1 \\
\hline Jenis Kelamin & $F$ & $\%$ \\
\hline Laki-laki & 16 & 43.2 \\
\hline Perempuan & 21 & 56.8 \\
\hline Status Perkawinan & $F$ & $\%$ \\
\hline Belum Kawin & 3 & 8.1 \\
\hline Kawin & 27 & 73.0 \\
\hline Janda/Duda & 7 & 18.9 \\
\hline Tingkat Pendidikan & $F$ & $\%$ \\
\hline $\mathrm{SD}$ & 6 & 16.2 \\
\hline SMP & 6 & 16.2 \\
\hline SMU & 18 & 48.6 \\
\hline Akademi & 2 & 5.4 \\
\hline PT & 5 & 13.5 \\
\hline Pekerjaan & $F$ & $\%$ \\
\hline Pelajar & 2 & 5.4 \\
\hline IRT & 12 & 32.4 \\
\hline PNS & 2 & 5.4 \\
\hline Wiraswasta & 1 & 2.7 \\
\hline Petani & 0 & 0 \\
\hline Pensiunan & 5 & 13.5 \\
\hline Pegawai & 2 & 5.4 \\
\hline Tidak Bekerja & 13 & 35.1 \\
\hline Penghasilan & $F$ & $\%$ \\
\hline Rendah & 27 & 73.0 \\
\hline Sedang & 2 & 5.4 \\
\hline Tinggi & 3 & 8.1 \\
\hline Sangat Tinggi & 5 & 13.5 \\
\hline Jumlah & 37 & 100,0 \\
\hline
\end{tabular}


Berdasarkan tabel 1 dapat disimpulkan bahwa dari 37 pasien hemodialisis yang mengalami depresi, kejadian terbanyak terjadi pada rentang usia 50-59 tahun sebanyak 15 orang $(40,5 \%)$, dengan jenis kelamin terbanyak adalah perempuan sebanyak 21 orang $(56,8 \%)$. Status perkawinan terbanyak yaitu status kawin sebanyak 27 orang $(73,0 \%)$, dengan tingkat pendidikan pasien terbanyak pada SMU sebanyak 18 orang $(48,6 \%)$. Pasien terbanyak tidak bekerja sebanyak 13 orang $(35,1 \%)$, dengan penghasilan terbanyak di kategori rendah sebanyak 27 orang $(73,0 \%)$.

\section{TABEL 2. DISTRIBUSI FREKUENSI PASIEN HEMODIALISIS BERDASARKAN TINGKAT DEPRESI}

\begin{tabular}{lcc}
\hline \multicolumn{1}{c}{ Derajat Depresi } & $\boldsymbol{F}$ & $\boldsymbol{\%}$ \\
\hline Depresi Ringan & 19 & 51,3 \\
Depresi Sedang & 16 & 43,2 \\
Depresi Cukup Berat & 2 & 5,5 \\
Depresi Berat & 0 & 0 \\
\hline \multicolumn{1}{c}{ Jumlah } & $\mathbf{3 7}$ & $\mathbf{1 0 0 , 0}$ \\
\hline
\end{tabular}

Berdasarkan tabel 5.3 dapat disimpulkan bahwa dari 37 sampel pasien hemodialisis, pasien mengalami depresi terbanyak pada tingkat depresi ringan $(51,3 \%)$.

\section{Pembahasan}

\section{A. Karakteristik Dasar Subjek Penelitian}

Berdasarkan usia dari 37 sampel pasien hemodialisis, kejadian terbanyak terjadi pada rentang usia 50-59 tahun yaitu sebanyak 15 orang $(40,5 \%)$. Hasil ini sejalan dengan penelitian oleh Fitri amalia, (2015) diperoleh hasil usia terbanyak pasien yang menjalani hemodialisis adalah $50-59$ tahun $(37,5 \%)$. Penelitian Rustina, (2012) diperoleh usia terbanyak adalah 45-56 tahun yaitu 40 orang (50\%) dan juga penelitian Pratiwi, (2014) diperoleh hasil usia terbanyak pasien adalah 41-50 tahun yaitu 13 orang $(43,3 \%) .^{10,11,12}$

Penurunan fungsi ginjal dalam skala kecil merupakan proses normal bagi setiap manusia seiring dengan bertambahnya usia. Usia merupakan faktor risiko terjadinya gagal ginjal kronis. Semakin bertambah usia seseorang maka semakin berkurang fungsi ginjal. Secara normal penurunan fungsi ginjal ini telah terjadi pada usia di atas 40 tahun. $^{13}$

Menurut Bare \& Smeltzer (2002) dalam Ardila (2014) mengatakan bahwa bertambahnya usia seseorang akan mempengaruhi perubahan pada fungsi renal. Pada usia setelah 40 tahun akan terjadi penurunan laju filtrasi glomerulus secara progresif hingga usia 70 tahun, kurang lebih $50 \%$ dari normalnya. ${ }^{14}$

Berdasarkan jenis kelamin dari 37 sampel pasien hemodialisis, kejadian terbanyak terdapat pada jenis kelamin perempuan sebanyak 56,8\%. Penelitian sebelumnya yang dilakukan oleh Rahayu H, (2019) diperoleh hasil paling banyak pasien hemodialisis adalah perempuan yaitu (52,9\%), dan penelitian Ilmi, (2016) diperoleh pasien perempuan yaitu $(41,9 \%))^{15,16}$

Penyakit ginjal kronik (PGK) lebih banyak diderita perempuan dibandingkan laki-laki. Beberapa penelitian menunjukkan, rata-rata prevalensi PGK sebesar $14 \%$ pada perempuan dan $12 \%$ pada laki-laki. Hal ini sesuai dengan teori yang dikatakan bahwa menurut peneliti di Amerika jenis kelamin perempuan termasuk kedalam delapan faktor resiko terjadinya $\mathrm{PGK}{ }^{14}$

Berdasarkan status perkawinan dari 37 sampel pasien hemodialisis, pasien terbanyak memiliki status kawin sebanyak 27 orang (73\%). Penelitian sebelumnya yang dilakukan oleh Rustina, (2012) diperoleh paling banyak pasien dengan status sudah menikah (95,5\%), penelitian Amalia, (2015) diperoleh semua pasien $(100 \%)$ sudah menikah dan penelitian Ilmi, (2016) diperoleh $(79,1 \%)$ pasien sudah kawin..$^{10,11,16}$ Berdasarkan tingkat pendidikan, paling banyak adalah tamatan SMA $48.6 \%$.

Penelitian sebelumnya yang dilakukan oleh Amalia, (2015) diperoleh paling banyak 
pendidikan pasien adalah SMU yaitu (43,7\%), penelitian Wahyuni, (2018) diperoleh pendidikan pasien paling banyak SMU $(48,4 \%) .^{10,17}$

Berdasarkan pekerjaan dari 37 sampel pasien hemodialisis, pasien terbanyak tidak bekerja yaitu 13 orang (35\%). Hasil ini sesuai dengan penelitian oleh Wahyuni, (2018) diperoleh hasil paling banyak pasien tidak bekerja $(58,1 \%) .{ }^{16,17}$ Pasien banyak tidak bekerja dikarenakan pasien hemodialisis harus menjalani pengobatan jangka panjang. Hemodialisis juga dapat menyebabkan pasien menjadi lelah sehingga pasien kebanyakan lebih memilih untuk fokus ke pengobatannya dan beristirahat.

Berdasarkan penghasilan dari 37 sampel pasien hemodialisis, pasien terbanyak berpenghasilan rendah sebanyak 27 orang.

Penelitian sebelumnya yang dilakukan oleh Rahayu H, (2019) diperoleh hasil paling banyak pasien dengan penghasilan rendah sebanyak $(97,6 \%)$, penelitian Hartini, (2016) diperoleh hasil paling banyak penghasilan pasien rendah yaitu $(43,3 \%)$ dan penelitian Rukmaliza, (2013) pada pasien gagal ginjal kronis yang menjalani hemodialisis di RSU Dr. Zainoel Abidin Banda Aceh paling banyak pada kategori tingkat penghasilan rendah yaitu 22 orang $(34,9 \%))^{15,18,19}$

\section{B. Tingkat Depresi}

Berdasarkan penelitian dari 37 sampel, didapatkan pasien lebih banyak mengalami depresi ringan. Penelitian sebelumnya yang dilakukan oleh Hedayati et al, (2006) yang menyatakan bahwa $26,7 \%$ pasien hemodialisis mengalami depresi ringan. ${ }^{11,27}$

Smith dalam Rustina, (2012) menyatakan bahwa prevalensi depresi mempunyai variasi yang sangat besar yaitu berkisar 0\%-100\%. Perbedaan ini tergantung pada beberapa hal, yaitu metode yang digunakan, jumlah sampel, waktu dan tempat pengambilan sampel serta ketelitian dan keahlian dalam pengambilan sampel. ${ }^{11}$
Pada penelitian ini didapatkan pasien terbanyak mengalami depresi ringan, ini dikarenakan pasien yang menjalani hemodialisis terbanyak pada rentang usia 50 - 59 tahun. Seseorang yang mempunyai usia lebih muda ternyata lebih mudah mengalami kecemasan dan depresi daripada seseorang yang lebih tua, tetapi ada juga yang berpendapat sebaliknya. ${ }^{28}$ Pada penelitian ini pasien terbanyak dengan tingkat pendidikan SMU, tingkat pendidikan setara SMU/SMK secara umum sudah termasuk dalam kategori yang baik sehingga responden sudah mampu mengontrol dan membangun tingkat emosi secara sempurna.

Notoatmodjo menyatakan bahwa semakin tinggi tingkat pendidikan akan semakin memengaruhi pola pikir seseorang dalam mengambil keputusan.Berdasarkan status pernikahan, pasien banyak yang berstastus menikah. Menurut peneliti dengan status menikah, pasangannya bisa mendukung pasien dengan memotivasi atau selalu ada di samping pasien. Hal tersebut mampu menurunkan tingkat stress ataupun depresi pasien hemodialisis tersebut.Banyak yang mengalami depresi ringan juga bisa disebabkan oleh faktor tempat tinggal dimana pada penelitian ini pasien terbanyak masih tinggal bersama keluarga intinya sehingga dia akan mendapatkan dukungan lebih baik dari keluarganya. ${ }^{23,28,29}$

\section{KeSIMPUlan Dan SARAN}

Pada penelitian dapat disimpulkan bahwa tingkat depresi yang terbanyak dialami oleh pasien yang menjalani hemodialisis adalah depresi ringan. Disarankan untuk melakukan penelitian lebih lanjut yaitu studi analitik untuk melihat hubungan tingkat depresi pada penyakit ginjal kronik. 


\section{Daftar Pustaka}

[1] KDIGO.Clinical practice guideline for the evaluation and management of chronic kidneydisease.2012.Tersedia dari:http://www.kdigo.org/clinical_practice_guid elines/pdf/CKD/KDIGO_2012_CKD_GL.pdf

[2] Henry Ford Health System. Chronic kidney disease: Clinical practice recommendations for primary care physcians and healthcare providers. Edition 6.0.2011.

[3] Badan Penelitian dan Pengembangan Kesehatan Kementerian Kesehatan RI. Riset kesehatan dasar. Bakti Husada; 2013.

[4] Badan Penelitian dan Pengembangan Kesehatan Kementerian Kesehatan RI. Riset kesehatan dasar dalam angka Provinsi Sumatera Barat. Bakti Husada; 2013.

[5] Guyton, Arthur C and John E, Hall. Textbook of Medical Physiology, 11th ed. Philadelpia : Elsevier-Saunders;2016.

[6] Azahra, Mega. Peran Konsep Diri dan Dukungan Sosial Terhadap Depresi pada Pasien Gagal Ginjal yang Menjalani hemodialisis. 2012. Yogyakarta: Fakultas Psikologi Universitas Ahmad Dahlan.

[7] Sadock's, Benyamin James, Virginia Alcott.Theories of personality and psychopathology, Mood Disorders, Kaplan \& Sadock's: Synopsis of psychiatry. New York. 2007; 197: 527-55.

[8] Andri. Gangguan psikiatrik pada pasien penyakit ginjal kronik. Bagian Psikiatri, Fakultas Kedokteran Universitas Kristen Krida Wacana.Jakarta, Indonesia. 2013; 40(4).

[9] Ahkari S, Moshki M, Bahrami M. Therelationship between social support and adherence of dietary and fluids restrictions among hemodialysis patients in Iran. Journal of Caring Science. 2014;3(1):11-9.

[10] Amalia F, Nadjmir, Azmi S. Gambaran Tingkat Depresi pada Pasien Penyakit Ginjal Kronik yang Menjalani Hemodialisis di RSUP DR. M. Djamil Padang. Jurnal Kesehatan Andalas .2015

[11] Rustina. Gambaran Tingkat Depresi pada Pasien Penyakit Ginjal Kronik yang Menjalani Hemodialisis di RSUD Dr. Soedarso Pontianak, 2012

[12] Pratiwi Desi G. Hubungan dukungan keluarga dengan tingkat depresi pasien gagal ginjal kronik dengan hemodialisis di RS PKU Muhammadiyah Yogyakarta ;2014

[13] Sidharta P, Mardjono M. Neurologi Klinis Dasar. Jakarta: Dian Rakyat;2008 .hal: 169-73.

[14] Ardila I, Sulistyaningsih, D R. Hubungan tingkat stres dengan kualitas hidup pasien penyakit ginjal kronik yang menjalani hemodialisis di rumah sakit umum daerah kota Semarang. Semarang;2014
[15]Rahayu Riski ,dkk. Respon Stres Pasien Gagal Ginjal Kronik Yang Menjalani Hemodialisis di Ruang Hemodialisis RSUD Dr.Hardjono Ponorogo; 2019

[16]Ilmi , Atika Nurul. Gambaran Gangguan Psikosomatik Pasien Penyakit Ginjal Kronik Di Rsup Dr.M.Djamil Padang ;2016

[17] Wahyuni,Putri. Hubungan Lama Menjalani Hemodialisis dengan Kualitas Hidup Pasien Penyakit Ginjal Kronik dengan Diabetes Melitus di RSUP Dr. M Djamil Padang, 2018

[18] Hartini S. Gambaran Karakteristik Pasien Gagal Ginjal Kronis Yang Menjalani Hemodialisis Di Rumah Sakit Umum Daerah Dr. Moewardi; 2016

[19] Rukmaliza. Hubungan Karakteristik Individu Dengan Kualitas Hidup Pasien Gagal Ginjal Kronik Yang Menjalani Hemodialisis di Instalasi Dialisis BLUD RSU DR. Zainoel Abidin Banda Aceh Tahun 2013. http://etd.unsyiah.ac.id;2013. Hlm 7-78

[20] Sukriswati, I. Hubungan dukungan keluarga dengan kualitas hidup pasien gagal ginjal kronik yang menjalani hemodialisis di RSUD Moewardi Surakarta. Skripsi. Program Studi Ilmu Keperawatan Universitas Muhammadiyah Surakarta;2016

[21] Saeed Zeb,dkk. Depression in patients on hemodialysis and their caregiver. Departement of nephrology and psychiatry, Federal sheikh zayed postgraduate medical institute, Lahore, national health research complex, Federal sheikh zayed postgraduate medical institute, Lahore, Pakistan;23(5):946-52;2012

[22] Vierdelina ,N. Gambaran Stres Kerja dan FaktorFaktor Yang Berhubungan Pada Pengemudi Bus Patas 9B Jurusan Bekasi Barat-Cililitan/Kampung Rambutan Jakarta: Fakultas Kesehatan Masyarakat Universitas Indonesia ;2008.

[23] Armaly, Zaher. 2012. Major Depressive Diorders in Chronic Hemodialysis Patients in Nazareth: Identification and Asessment. Neuropsychiatric Disease and Treatment: Dove Press;2012

[24] Wijaya ,A.Kualitas Hidup Pasien GGK yang Mengalami Hemodialisis dan Mengalami Depresi. Skripsi. Jakarta: FKUI.2005

[25] Departemen Kesehatan Republik Indonesia. Pharmaceutical Care untuk Penderita Gangguan Depresif. Direktorat Bina Farmasi Komunitas dan Klinik Ditjen Bina Kefarmasian dan Alat Kesehatan Depratemen Kesehatan Republik Indonesia;2007

[26] Nurchayati , S. Analisis faktor-faktor yang berhubungan dengan kualitas hidup pasien penyakit ginjal kronik yang menjalani hemodialisis di Rumah Sakit Islam Fatmawati Cilacap dan Rumah Sakit Umum Daerah Banyumas.Tesis Universitas Indonesia.Depok;2010 
18 Heme, Vol II No 1

January 2020

[27]Hedayati, S.S., \& Fredic, O.F. Epidemiology, Diagnosis, and Management of Depression in Patient With CKD. Am J Kidney Dis;2009

[28] Varcarolis, E.M.Psychiatric Nursing Clinical Guide: Assessment Tools \& Diagnosis. Philadelphia: W. B. Saunders Company;2000

[29] Stuart.Gail.W. Keperawatan Kesehatan Jiwa : Indonesia: Elsever;2016 